\title{
Research on the Modes of Rural Information Construction
}

\author{
Xing Huang ${ }^{1,2}$, Xiaofeng $\mathrm{Li}^{1}$ \\ ${ }^{1}$ China Agricultural University, Beijing, China \\ ${ }^{2}$ China West Normal University, Nanchong, Sichuan Province, China
}

Keywords: Informatization, Marketization, Village Service Station.

\begin{abstract}
Ministry of Agriculture put forward Agricultural Rural Development Planning of 13th Five-year , by which we would achieve great progress in the next five years on the rural informatization constructions, those works' base and main supports were the realization of taking information into villages as well as doors, that was to set up the village service stations. While there was currently Government Leading Mode in practice, this mode cost largely with low energy and unobvious motivation effects. Thus the author proposed another mode for informatization by marketization, to draw into the companies with powers and driving forces, Public-Private-Partnership Mode with government, to realize each objectives on economics and societies, then to gain the benefits and welfare maximization at last.
\end{abstract}

\section{Introduction}

August 30, 2016, the Ministry of Agriculture issued the National Development Plan on Agricultural and Rural Information Construction during the 13th Five-Year. [1] It is the subplan of National Agricultural Modernization Plan (2016-2020), and the guidance of carrying out the project of agricultural and rural information construction. At the beginning of this plan, it is pointed out that information construction is the commanding point of agricultural modernization. The transformation from industrialization to information construction and the transformation from agricultural modernization to agricultural information construction are milestones in the history of human progress and agricultural development. The 9th Five-Year period is the initial stage of agricultural information construction in China. In the twenty-first century, the agricultural and rural information construction in China develops rapidly in theory and practice. At the turn of the century, a scholar (Fang-quan Mei, 2001) [2] pointed out that in the process of agricultural development, China should implement the strategy of "information spanning" and establish the line of "building powerful country through information". With the rapid development of information technology and related in-depth research and practice, agricultural and rural information construction has stepped into a more specific and detailed stage from the initial agricultural information stage. Therefore, the central government puts forward to the National Development Plan on Agricultural and Rural Information Construction during the 13th Five-Year.

Information refers to the transmission and processing objects in messages, news and communication systems. Generally speaking, it includes all contents which are spread in human society. People distinguish things by acquiring and identifying information, and then they can recognize and transform the world. In 1948, mathematician Nong Xiang pointed out, "information is used to eliminate stochastic uncertainty." [3]In narrow sense, information means the resources of information, namely the ordered collections of useful information after processing. The generalized definition of information is a general term which includes information, information producers, information technology and funds. The particularity of information resources is manifested in its sharebility, mobility, diversity, inseparability and cost consistency. 
There are three kinds of definition on information construction: (1) the general term of communication, computerization and behavioral rationality; (2) the modernization of computers, communication and network; (3) information activities, including information production, dissemination and use; it is a kind of social economic phenomenon (Long-qing Zhang, 2003). In general, information construction refers to the development of new productivity represented by computer and other intelligent tools, and its benefits for the society. It includes computerization, networking and intelligence [3].

Agricultural information construction emerged later than the information construction of national economy. In a narrow sense, it is the digitalization of information resources and the networking of information exchange; it is included in the process of modernization. In a broad sense, it is the information construction of the whole process of agriculture, including farmers' living consumption, agricultural infrastructure, agricultural science and technology, agricultural management, as well as agricultural resources and environment. Rural information construction is the universal application and popularization of communication and computer technology in production, life and social management in rural areas. [4]

Generally speaking, rural information construction is an integral part of agricultural information construction. It is more detailed, more specific and deeper than agricultural information construction. To realize rural information construction, agricultural information construction must be realized first. From another perspective, agricultural information construction focuses on the information construction of objects; it tries to realize the automation of traditional production process, in order to reduce costs and improve efficiency. The rural information construction focuses on the information construction of human beings. It is a social concept, which does not only contain rural production links, but also cover all aspects of human activities, including farmers' entertainment, education and learning.

\section{Literature Review}

Literature review abroad. The progress of agricultural information construction can be divided into three stages on the international. The first stage (1950s-1960s) is the information construction of communication equipment such as radio and telephone. The second stage (1970s-1980s) is the information construction of agricultural knowledge, data processing, database development and operation. The third stage (since 1990s) is the synchronous information construction of information network, multimedia and the automatic control of agriculture production.

Like the process of agricultural modernization, agricultural information construction is also a long-term process. Every country in the world has their own characteristics in the period, mode, degree and type of information construction. Judgment indicators on the level of agricultural information construction are also different. At present, the leading countries in the world are the United States, Germany, France, Britain, Japan, South Korea and other developed countries. India, Russia and other developing countries are also promoting rural information construction, and have summarized many experiences which can be used for reference.

As the most developed country in economy, technology and electronic information industry, the United States has constructed a agricultural information network at three levels: country, region and state, and formed the agricultural information service system (Yuan-feng Zhao, 2002) [5]. Germany pays attention to the training of information security, and formulates relevant laws (Ji-fen Liu, 2004, Feng-cui Fan et al., 2006) [6]. France is the largest agricultural producer in the EU, and its multi-cultural background determines the coexistence of multiple services in agricultural information construction (Ying Shen, 2002; Guo-sheng Cui et al., 2004) [7]. Japan has its characteristics in refining and regionalization; laws and regulations in Japan are relatively strict (Feng-ping Meng, 2003; Yi Yang; 2005) [8]. The development of South Korea starts relatively late, so Koreans adopt the "catch up" model and pay attention to the effectiveness of agricultural information technology applications (Feng-ying Nie, 2004) [9]. India, a developing country, relies on its highly developed software industry to speed up agricultural information construction (Liang-yu Chen, 2004) [10]. 
To sum up the statuses of agricultural information construction of above countries, following conclusions can be drawn. (1) ICT information and communication technology are the key of agricultural information construction; all countries have implemented a series of infrastructure projects on the basis of information and communication technology. (2) Attentions need to be paid to the development of practical information resources in directly related areas, such as rural management, agricultural production, agricultural science and technology, social life and production circulation. (3) The government should serve as the main body and lead the development of information resources. (4) Attentions need to be paid to education; rural people with different gender and different levels of education should be trained differently to improve the utilization efficiency and the benefit of information. These experiences of different countries have specific applicability and specificity, and they need to be considered and studied carefully before applying to the reality of our country.

Literature review in China. Domestic researches focus on two angles and three categories. The first angle is the development strategy of agricultural information construction on the national level; the second angel is the agricultural information construction status and development strategy on the local level. The three categories (according to research subjects) are government departments, research and technological institutions, institutions of higher learning. Through the analysis of two important research funds, the National Social Science Fund and the National Science Foundation, this article shows domestic research status on agricultural and rural information construction to a certain extent.

Researchers analyzed projects on agricultural information construction in national social science projects [11].Firstly, researchers searched "rural information construction" and "agricultural information construction". After analysis, it is found that there are two items on agricultural information construction and rural information construction respectively; researches mainly belong to the subject of library- information and documentation science. The research on agricultural information construction was done in 2005. Deep study on rural information construction began at 2009 and 2015.

We searched agricultural and rural information construction, and found no related items. Then we expanded the item as "information construction", and access to information of 89 projects; 15 projects relate to agriculture.

According to the analysis of project categories and items, most projects related to "information construction" are general projects (62), followed by youth projects (12), western projects (8) and key projects (7).The number of projects increased from 1996, and reached to the highest in 2002 (14), then stabilized at less than 10 . Recently there is an upward trend as the result of national planning.

We searched national science foundation projects according to the item of "information construction", and found 49 projects from 1999 to 2016. But there's only one project which is related to agriculture. Thus, there's little research and application on agricultural and rural information construction in the field of natural science.

Table 1 national science foundation projects: information construction (total 49), including1 agriculture-related project

\begin{tabular}{|c|c|c|c|c|c|c|}
\hline $\begin{array}{l}\text { Project } \\
\text { No. }\end{array}$ & Year & Type & Project & discipline & $\begin{array}{l}\text { Project } \\
\text { leader }\end{array}$ & Unit \\
\hline $\begin{array}{l}40901 \\
068\end{array}$ & 2010 & $\begin{array}{l}\text { Youth } \\
\text { Project }\end{array}$ & $\begin{array}{l}\text { Research on ChineseRural Space } \\
\text { Organization under the Influence of } \\
\text { Informatization Trend }\end{array}$ & $\begin{array}{l}\text { geograp } \\
\text { hy }\end{array}$ & $\begin{array}{l}\text { Jiang-hui } \\
\text { Ding }\end{array}$ & $\begin{array}{l}\text { Hebei } \\
\text { Normal } \\
\text { University }\end{array}$ \\
\hline
\end{tabular}

\section{Analysis of the Plan}

Apart from layout leading and guidance, National Development Plan on Agricultural and Rural Information Construction during the 13th Five-Year also provides quantitative targets as shown in Table 2. In the table, the third indictor, coverage rate of village level information service station, needs to increase from $1.35 \%$ in 2015 to $80 \%$ in 2020;the average annual growth rate should be 
$126.2 \%$. It is an infrastructure project which needs vigorously promotion. The second indicator, the proportion of online retail sales of agricultural products accounted for the total agricultural output, should increase from $1.47 \%$ in 2015 to $8 \%$ in 2020; the average annual growth rate should be 40.3\%.It indicates that the electricity agricultural and rural commerce needs to be developed. According to rural planning index, by 2020,the Internet popularizing rate will be more than a half. It includes not only the accessibility of network, but also farmers' cognition level and ability to use the Internet. Therefore, relevant training is essential. By the end of 2020, the four modernizations of agricultural information will be fully realized: intelligent production, network operation, management defamation and online service.

Table 2 Main indicators of agricultural and rural information construction during 13th Five-Year(\%)

\begin{tabular}{llll}
\hline Indicator & $\mathbf{2 0 1 5}$ & $\mathbf{2 0 2 0}$ & $\begin{array}{l}\text { Averageannua } \\
\text { I growth rate }\end{array}$ \\
\hline $\begin{array}{l}\text { 1.Applications ratio of information technology } \\
\text { 2.Agricultural products online retail volumeto total }\end{array}$ & 10.20 & 17 & 10.8 \\
agricultural output & 1.47 & 8 & 40.3 \\
$\begin{array}{l}\text { 3.Coverage rate ofvillage level information service } \\
\text { station }\end{array}$ & 1.35 & 80 & 126.2 \\
4.Internetpopularizing rate & 30.30 & $>51.6$ & $>9.8$ \\
\hline
\end{tabular}

\section{Case Analysis}

At present, the level of rural information construction in China is still at the stage of government led with fewer facilities, lower utilization levels and less vitality. By the end of 2015, there were only more than 9000 village information service stations which can serve surrounding households; the coverage rate was only $1.35 \%$.

Model 1: government-leading. Construction of village level service station in Gansu province; Gansu has pilots and classification. By means of questionnaire and on-the-spot investigation, information resource in villages, the location of service stations and the demands of farmers are collected. The locations are selected after comprehensive consideration about wishes of local agricultural sectors, local government, village committees, operators and farmers. 50 demonstration village information stations were built in demonstration villages and administrative villages. In 2015, 133 village level information service stations have been set up, accounting for nearly $40 \%$ of the total number. 2 pilot counties, especially the county of Ningxian strengthen the financial integration. Gangu County installed touch screens, electronic displays and bank POS machines in 8 demonstration village stations, and equipped a full-time information officer. The county fiscal department gives the officer 18 thousand yuan a year(i.e. 1500 yuan per month) as subsidy. Ningxian County built 125village stations, among which are 46standard stations, 43 professional stations and 36 simple stations.

Construction of village level service station in Fuqing of Fujian Province. Fuqing is a county-level city; it is directly under the governance of Fuzhou city. Fuqing located in the southeast coast of Fujian province. It is a new, modern industrial port city with 17 towns, 7 streets and 475 natural villages (communities). The area of this county is about 1519 square kilometers, the household population is about 1 million 259 thousand. Between 2010 and 2013, the growth rate of GDP in Fuqing was above $10 \%$, higher than the national average level. In 2010, Fuqing invested about 3 million yuan to build or renovate village service stations. At the end of 2011, 29 village level service stations had been built or rebuilt. By the end of 2013, the number became 127, accounting for $1 / 3$ of total administrative villages. But the overall coverage of village level service stations remained low. The fund comes from the central government, municipal finance department and towns. The construction area is 200-300 square meters, which is three times of the original number.

Model two: market integration. Information platform on the basis of the peasant household bookstores. Peasant household bookstores project is one of the five people-benefit cultural projects (proposed at the 17th National Congress: Radio, television, film, bookstore, Western and cultural resources sharing). In 2005, the pilot projects were built. In 2007,the project was comprehensively 
launched (jointly launched by the Press and Publication Administration and Seven Ministries and Commissions). In order to meet the cultural needs of farmers, bookstores are built according to the standard of 20 thousand yuan in all administrative villages. At the end of August 2012, household bookstores have covered all administrative villages. In China, total 600449 rural bookstores have been built, with a total investment of about 18 billion yuan. The central special funds also provide 600 million yuan per year for the supplement and updating of books.

Due to public welfare and management problems, some resources are wasted. In October 27, 2015, the Urban and Rural Overall Development Research Center and Kim Chaek Tong (Beijing) Technology Co., Ltd. signed a cooperation agreement. Based on peasant household bookstores, they would jointly develop and construct rural information service platform.

This project is based on the rural bookstore, and aims to realize the rural information construction landing under the commercial market operation mode. City and county e-business refers to the process of using information technology such as Internet, computer and multimedia, providing peasants online service on the sale, purchase and payment of agricultural products. In China, city and county e-commerce business information platforms can be divided into three groups. 1) e-commerce platform like logistics and sales of agricultural products, such as Tmall, Jingdong and so on; 2) commodity trading platform, such as rice, coal and so on; 3) information services like financial services, capital operation and investment promotion, such as advertising, fixed assets invigoration and consumer finance.

The development and fruits of city and county e-business -- peasant household bookstore cooperation are the signing of strategic contracts with the city or county government, and the signing of exclusive contracts with the household bookstore for ten years. At present, provinces that have carried out the business include Fujian, Anhui, Shanghai, Guangdong, Shandong and Hebei. Provinces which are going to carry out the business include Beijing, Tianjin, Jiangsu, Zhejiang, Guizhou and Guangxi. According to the plan, by the end of 2016, not less than ten provinces will have a total of more than 10000 terminal nodes. Profit models mainly include four major businesses: express delivery, electricity providers, finance and sub public. The project has bright prospects, but the investment is huge, while the operation and promotion are complex and difficult. Therefore, in reality, the government and enterprises need to work together to promote rural information construction and infrastructure platform construction.

In general, the government leading mode is costly, and lack of vitality and power in the long time operation. It cannot satisfy the needs of rural information construction on village and household levels. Market integration model introduces mature enterprises through the market, and has strong driving force, as well as operation and management abilities. It can inject fresh blood and vitality for the sustained growth of rural information construction.

\section{Conclusion: To Promote Information construction through Marketization}

PPP model (Public-Private-Partnership) is the formation of partnership between the government and private organizations in order to provide public goods and services. It is built on the basis of franchise agreement and signed contract. Through cooperation, both parties can achieve more favorable results. The public private partnership model (PPP) has attracted wide attention both at home and abroad for the participation of government during the whole process. The PPP model transfers a part of government's responsibility to social subjects (enterprises) through franchise rights; the government and enterprises can establish the relationship of "sharing benefits and risks, and cooperating in the whole process". It lightens government's financial burdens and enterprises' investment risks. At the same time, due to the prosperity of the market, it can open up new space for the development of rural markets and the transformation of the rural labor force [12].

Market operation has long-term sustainability. Now in our country, the agricultural and rural information construction during "13th Five-Year" is in full swing. The "visible hand" - government and the "invisible hand" - market should cooperate and play their roles, trying to promote rural information construction in the process of marketization. 


\section{Acknowledgement}

Project Foundation: This paper is supported by MOE (Ministry of Education in China) Liberal arts and Social Sciences Foundation (12YJC79015) and Excellence Foundation of China West Normal University (17YC107).

\section{References}

[1] http://www.moa.gov.cn/zwllm/ghjh/201609/t20160901_5260726.htm[DB/OL], official website of Ministry of agriculture, 2016-8-30.

[2] Fang-quan Mei. Strategic Analysis of Agricultural Modernization Driven by Agricultural Informatization [J]. Chinese Rural Economy, 2001(12): 22.

[3] http://baike.so.com/doc/933443-986650.html[DB/OL], Baidu Encyclopedia, 2014-12-29.

[4] Rural informatization, Baidu Wenku, http://wenke.baidu.c, [DB/OL]-2014-12-10.

[5] Yuan-feng Zhao. Characteristics of Agricultural Informatization in Developed Countries [J]. Chinese Rural Economy, 2002, (7).

[6] Ji-fen Liu. Status Quo and Development Trend of Agricultural Informatization in Germany [J]. WORLD AGRICULTURE, 2003(10): 36-38.

[7] Ying Shen. Developing Trends of Agriculture Informalization Abroad [J]. WORLD AGRICULTURE, 2002(1): 43-45.

[8] Feng-ping Meng. Main Characteristics of Information-oriented Agiculture in Japan [J]. WORLD AGRICULTURE, 2003(4):38-39,47.

[9] Feng-ying Nie, Ji-fen Liu, et al. The Process and Development of Agricultural Informatization in Major Countries of the World [J]. Agricultural network information, 2004,(9):15-17.

[10] Liang-yu Chen. Practice and Reference of Agricultural Informatization in India [J]. WORLD AGRICULTURE, 2004(10): 38-39.

[11] http://www.npopss-cn.gov.cn/ [DB/OL], National Planning Office for philosophy and Social Sciences - People's Network, http://fz.people.com.cn/skygb/sk/index.php/Index/seach, National Social Science Foundation Project Database, 2016-12-21

[12] Xiao-feng Li. Research on Non-governmental Financing of New Rural Informatization Construction [J]. MARKET MODERNIZATION, 2009(11): 94-95. 